\title{
AUGUSTUS, AGRIPPA, THE ARA PACIS, AND THE COINAGE OF 13 BC $^{*}$
}

Summary: In $13 \mathrm{BC}$, Augustus returned to Rome from a lengthy tour of the western provinces, just as Agrippa returned from the East. All conditions had been readied to present to the Roman people the establishment of Agrippa as the new partner of Augustus' labours after a multi-year build up, culminating in the Ara Pacis ceremony at which Agrippa co-presided. However, to those watching the political slogans and headlines of the Roman mint, the Ara Pacis ceremony and Agrippa's prominent role therein did not bring news, for the coinage of 13 boldly proclaims Agrippa as if he were second princeps by advertizing his enhanced status and by highlighting his accomplishments beyond the level ever provided for any of Augustus' other colleagues, including his eventual successor, Tiberius (whose own enhancement of powers after $\mathrm{AD} 4$ was modeled upon the precedent of Agrippa).

The coinage of $13 \mathrm{BC}$ represents a break from the recent general pattern in that it broke up Augustus' quasi-regal domination of the mint, and it sent out two simultaneous and compatible messages. Firstly, and more specifically, the imagery informed the Roman public as do newspaper headlines today of the elevation of Agrippa as Augustus' legal equal, showing that Rome was no monarchy. The Roman mint alternated between standard issues for certain messages and new images for others, including escalation of the status of Agrippa.

The year 13 provided several occasions to raise the status of Agrippa, a novus homo. Agrippa was offered a third triumph, which he again refused. He received a new priesthood(s). His tribunician power was renewed for five years, as was that of Augustus. And at the Ara Pacis ceremony, Agrippa shared equal credit for pacifying the Empire in a ceremony that may have included closing the Gates of Janus. Much of this information comes to us not just from textual evidence, but also the archeological record. The coinage of 13 informs us of the regime's official statements and the Ara Pacis itself shows the veiled Augustus at the head of the Pontifical College and the veiled Agrippa completing the Pontifical College and starting the imperial family as a demonstration of his integral role in the state, although tragically his life would end before the Ara Pacis was completed, leaving it to be a monument of a vision of the future Augustus was never able to achieve.

Key words: Augustus, Agrippa, Julio-Claudian dynasty, Imperial Roman coinage, Roman numismatics, Ara Pacis

* Presented at the conference XIV A.D. AVGVSTVM SAECVLVM, University of Lisbon, 24-26 September 2014. 
In the year $13 \mathrm{BC}$, Augustus and Agrippa returned to Rome amid great fanfare and celebration with many indications that the regime was about to present to the public a new statement of its goals and status. We should call this occasion the "Third Constitutional Settlement", although its plans were upset and rendered void by events immediately after. Agrippa's return to Rome with Julia and Augustus marked his rise to equal legal power such that everyone understood that should the "Holy One" die suddenly, Agrippa would be the man to ensure the stability of the state through his vastly superior auctoritas over everyone else, a standing revealed to the public through the escalated powers and honors Agrippa had of recent accumulated. This was best indicated to the public and to us through the coinage of 13, which differs greatly from the previous years, by purposefully enhancing and advertising Agrippa as the true partner of Augustus. Although Augustus was not yet ready to call himself emperor for fear of the resentment and possible conspiracies it might provoke, he was willing to present himself and his partner Agrippa as the plural leaders of the state - and by the very fact of their dual number to refute any charges of monarchy.

The epiphany for this truth came to me in 2002 when I was in the Riga History and Navigation Museum and saw their small display of Roman coins found on Latvian soil, which included an Augustus/Agrippa denarius that explained Agrippa was the second emperor of Rome. Initially I laughed at how the museum had expressed the facts, as we all consider Tiberius to be the second emperor, however, as I thought about it, I changed my mind. Agrippa possessed all the honors and powers that Tiberius later received which made him emperor: multiple consulships, triumphs, tribunicia potestas, maius imperium, multiple priesthoods, and a chain of advertisements on coinage to announce his elevation. In short, the only reason most scholars do not think to call Agrippa the second emperor of Rome is that premature death cut short his brief term in power, and more specifically and significantly, unlike Tiberius, he did not outlive Augustus.

Prior to 16 BC, Agrippa had amassed a considerable résumé that no one else in the Empire besides Augustus could equal and only Statilius Taurus, the second marshal of the regime could approach. Agrippa beyond doubt outpaced Tiberius, Drusus, Messalla Corvinus, and Maecenas in honors and real power. As a matter of fact, many scholars forget that as Agrippa's son-in-law, Tiberius was a client and essentially a surrogate son, so every honor he received during this time indirectly honored Agrippa. Agrippa's honors included three consulships (37, 28, $27 \mathrm{BC})$, multiple priesthoods (Vell. 2. 127. 1), the receipt of maius imperium in $23 \mathrm{BC}$, three triumphs in 37,19 , and again in $13 \mathrm{BC}^{1}-$ all of which he turned down, the receipt of tribunicia potestas in $18 \mathrm{BC}$, which was renewed in $13 \mathrm{BC}$, and although their importance was insufficiently understood at the time - the hand of Julia in marriage in $21 \mathrm{BC}$ and the adoption by Augustus of Gaius and Lucius in 17 BC.

Nevertheless, despite this accumulation of honors and powers, many still regarded Agrippa as an unpalatable upstart because he was a novus homo. In advancing Agrippa, Augustus faced a real challenge which had not been a problem with Marcellus,

\footnotetext{
${ }^{1}$ Dio Cass. 48. 49. 3-4, 54. 11. 6, 54. 24. 7. See Rich, J. W.: Cassius Dio: The Augustan Settlement. Warminster 1990, 202. 
exactly because Marcellus had the ancestry that made him a peer to the greatest houses of the Republic, descending directly from Venus, the kings Numa Pompilius and Ancus Marcius, Attus Clausus, and M. Claudius Marcellus the five-time consul (222, 215, 214, 210, 208 BC), winner of the spolia opima and hero of the Hannibalic War. Agrippa had no such ancestry. Because Augustus's top concerns were to maintain the stability of the state and to avoid a new series of civil wars at his death, once he had decided Agrippa as the best man to continue his policies, his task was to advance Agrippa above challenge by any other so that all would have no alternative but to accept him as the next princeps senatūs. This required expanding Agrippa's sacral and legal standing above all others in a series of novel and traditional steps. We best see these steps from the pages of Dio and the coinage of 20-13 BC, especially in the last year of Agrippa's life.

In the 20s, Augustus had limited who could appear on coinage issued from the Roman mint almost exclusively to himself. The Roman mint became Augustus's fief. ${ }^{2}$ Few if any coins from the Roman mint from 30-15 BC advertise any other magnate, not even Agrippa, although provincial governors continued to mint their own likeness from colonial mints. However, during the 30s and again in 20, a few Agrippa coins indicate his partisanship, loyalty, and general high status (Figs. 1-4). Their relative frequency compared to other generals may seem to suggest his increased importance at this early date, but the numbers are so small that one should not overstate the case. These few examples establish that Agrippa was an important figure in the $30 \mathrm{~s}$, but do not by any means prove that he was Augustus's heir or unofficial successor at this early date. When the city of Nemausus (Nîmes) was founded in $20 \mathrm{BC}$, the veterans recognized Augustus and Agrippa as their founders on a famous dupondius featuring the crocodile (Fig. 5). Again, while a great many dupondii were minted, and Agrippa had at this point already married Julia, the coin does not signal Agrippa's rise as Augustus' equal on a national scale. As Michael Grant has shown, several other individuals at that time minted founder-type coins for new cities and credited themselves either by name or by portrait.

Furthermore, as Michael Grant has shown, ${ }^{3}$ several other individuals minted founder-type coins or medals and credited themselves by name and/or portrait for their efforts. And as David Sear meticulously documented, many imperatores of the 40s and 30s minted coins to proclaiming their rank and status and partisanship, as do the Agrippa denarii in 38 BC. ${ }^{4}$ Just to provide three examples, Domitus Calvinus boasted his second consulship in $40 \mathrm{BC}$ on this denarius (a damaged version of which I own) at a time when he and Lepidus were the only living two-time consulars (Fig. 6). I also own this denarius of Salvidienus Rufus, who anticipated Agrippa with his own legend Q.SALVIVS IMP.COS. DESIG accompanied by a thunderbolt to express the

2 Contra P. ZANKER's suggestion (The Power of Images in the Age of Augustus. University of Michigan Press 1990, 14) that ordinary Romans often did not understand coin propaganda. If they did not, Augustus would have no reason to control so monoplisticly the coin issues.

${ }^{3}$ GRANT, M.: From Imperium to Auctoritas. Cambridge 1946, passim.

${ }^{4}$ SEAR, D. R.: The History and Coinage of the Roman Imperators 49-27 BC. London 1998, 187188. 

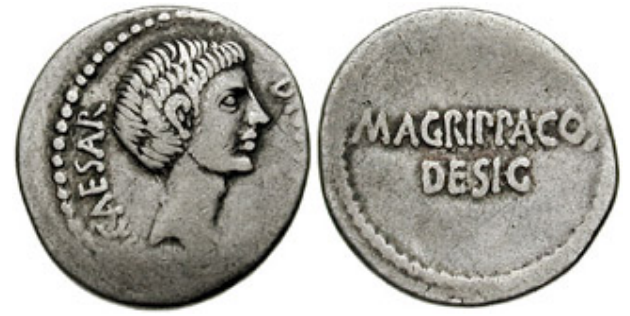

Fig. 1. Obv.: CAESAR DIVI F, rev.: $\mathrm{M} \cdot A$ GRIPPA.COS DESIG
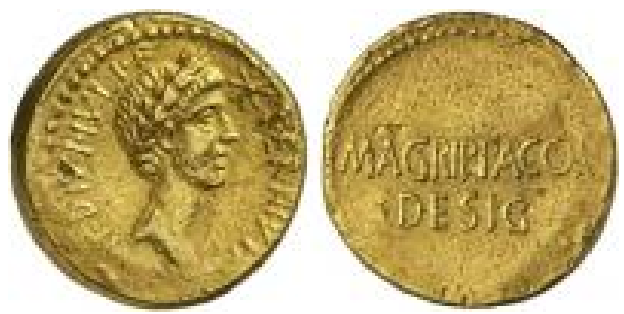

Fig. 3. Obv.: IMP·DIVI·IVLI·F·TER III $\cdot V I R \cdot R \cdot P \cdot C$, rev.: M·AGRIPPA·COS DESIG
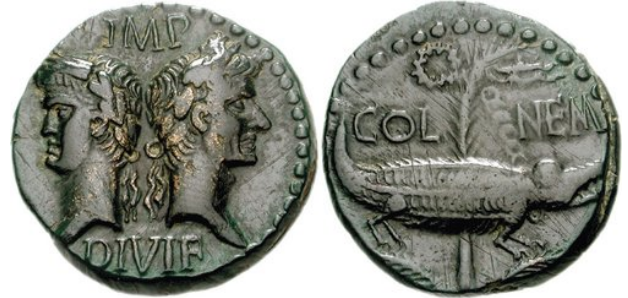

Fig. 5. Nemausus aes, 20 BC. Obv.: Augustus and Agrippa wearing oak and rostral-mural crowns, IMP P P DIVI F, rev.: crocodile (legionary emblem) palm tree, COL NEM

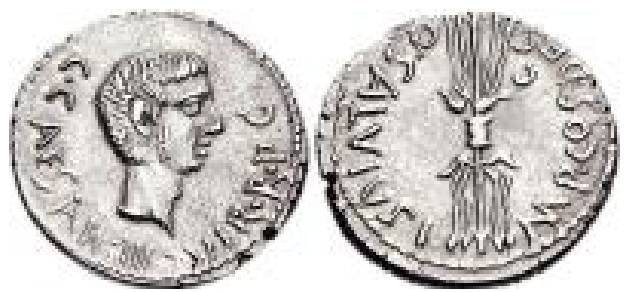

Fig. 7. Salvidienus Rufus, denarius, 40 BC. Obv.: C CAESAR III VIR R P C, rev.: thunderbolt, Q SALVIVS IMP COS DESIG
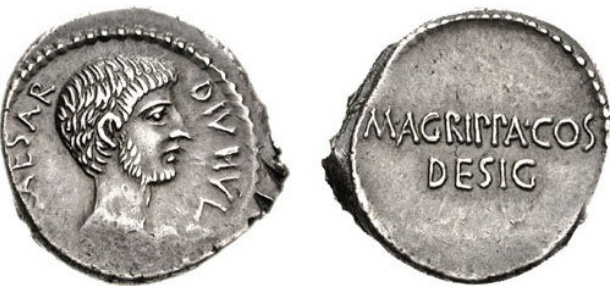

Fig. 2. Obv.: [IMP] CAESAR DIVI IVLI [F], rev.: M·AGRIPPA·COS DESIG
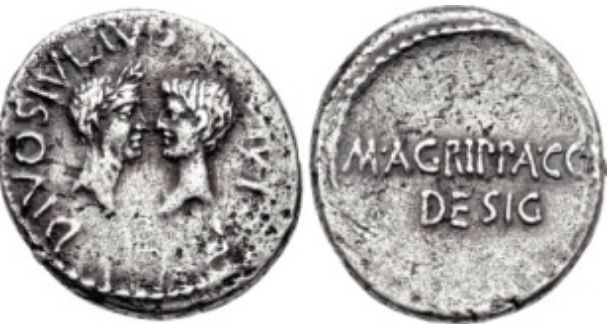

Fig. 4. Obv.: DIVUS IULIUS DIVI F, rev.: M·AGRIPPA·COS DESIG
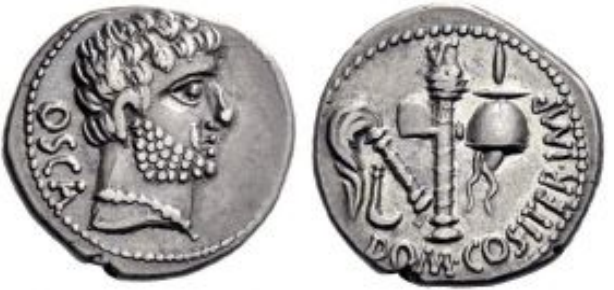

Fig. 6. Domitius Calvinus, denarius, Osca mint 39 BC. Obv.: bearded portrait OSCA,

rev.: simpulum, aspergillum, axe, galerus, DOM COS ITER IMP (symbols of the Caesarian faction).
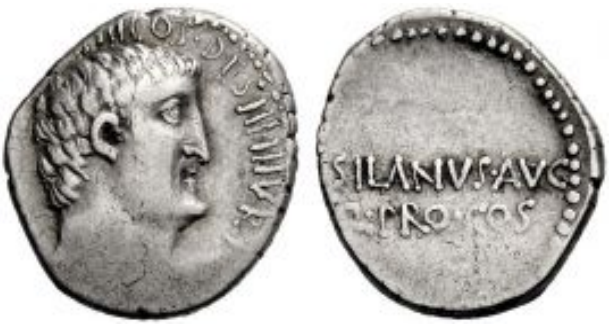

Fig. 8. Antony, denarius, 32 BC. Obv.: ANTON AVG IMP III COS DEC III III V R P C, portrait of Antony, rev.: M.SILANUS AUG Q PRO COS. 


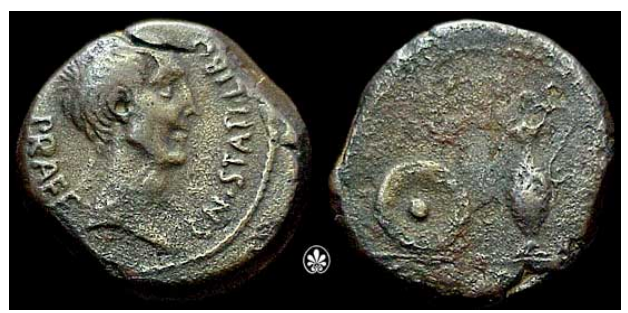

Fig. 9. Libo, denarius, Hispania.

Obv.: head of Libo [CN STATI] LIBO [PRAEF], rev.: SACERDO Patera, capis.

approval of the gods, right before his downfall (Fig. 7). In 40 BC, Salvidienus Rufus, not Agrippa, was the right hand of the Young Caesar. Similarly, in 33 BC, M. Junius Silanus, advertised himself as the top quaestor on a denarius with the simple reverse M.SILANUS AUG.Q.PRO.COS much like that of Agrippa in 38 BC (Fig. 8). And soon after Agrippa shared the consulships of 28 and 27 BC with Augustus, Silanus did the same in 25 BC. Cn. Libo, as governor of Spain, like many other governors, minted coins of himself (Fig. 9).

And Agrippa was in for a very rude awakening when Augustus began to show a preference for Agrippa's inexperienced brother-in-law Marcellus in 24/23 BC. Agrippa's pique grew so hot he took his wife and left Rome for Lesbos in $23 \mathrm{BC}$, refusing to perform the official duties Augustus gave him to disguise their rupture from the public. In short, the early Agrippa coins may foretell a great political future, but not to the level of indicating that he was being groomed to be the partner in Empire. Only the accumulation of honors that began in $18 \mathrm{BC}$ and greatly escalated in $13 \mathrm{BC}$, as is shown by the coinage of that year, reveals the fact that Agrippa had become the junior emperor on an unofficial throne.

Augustus and Agrippa spent the years 16-13 BC on tour of the provinces, Agrippa in the East; Augustus in Hispania, Gallia, and Germania. Julia accompanied Agrippa to Asia Minor but almost drowned in a flash flood of the Scamander near Troy. ${ }^{5}$ On this tour she gave birth to their two daughters Agrippina and Julia the Younger, who were too young for the public celebrations that greeted their return to Rome, and therefore are not seen on the Ara Pacis. ${ }^{6}$ The consecratio of the Ara Pacis was celebrated as the most important festivity of summer $13 \mathrm{BC}$, perhaps in conjunction with the third closure of the Gates of Janus. The frieze of the Ara Pacis shows several clues of Agrippa's rise in status that match a number of coins from 13 BC, but have not been fully appreciated as signals of Agrippa's new elevated status.

\footnotetext{
${ }^{5}$ Nic. Dam. frg. 134.

${ }^{6}$ As proof, note that Agrippina married Germanicus ca. AD 5 when he was nearly 20 and she was younger, whether by a few months or a year is unknown. One assumes she was born in 14, Julia in 13, and Agrippa Postumus in 12. L. Powell (Germanicus: The Magnificent Life and Mysterious Death of Rome's Most Popular General. Pen and Sword 2013, 4) perversely dates Germanicus's birth to 16 when we know the exact date as 24 May 15 BC. The text of Powell's n. 24 reference does not verify what he claims.
} 


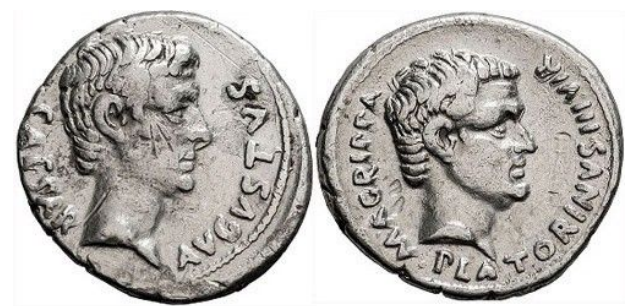

Fig. 10. Augustus and Agrippa, denarius, Rome, 13 BC. Obv.: bare head of Augustus right, rev.: M AGRIPPA PLATORIN[VS IIIVIR], bare head of Agrippa right (RIC 408; BMC 114; RCV 1726).
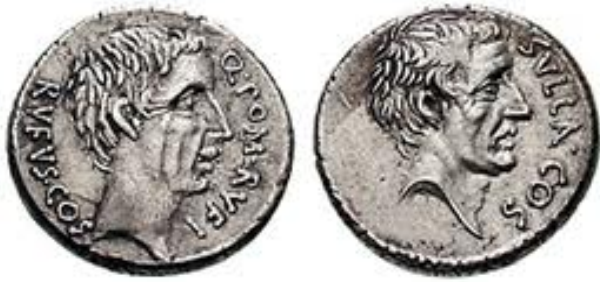

Fig. 11. Q. Pompeius Rufus, denarius, 54 BC. Obv.: head of Sulla, rev.: head of Q. Pompeius Rufus, evoking an ancestor and partisanship (Babelon Cornelia 48 and Pompeia $4=$ Sydenham $908=C r$ 434/1).
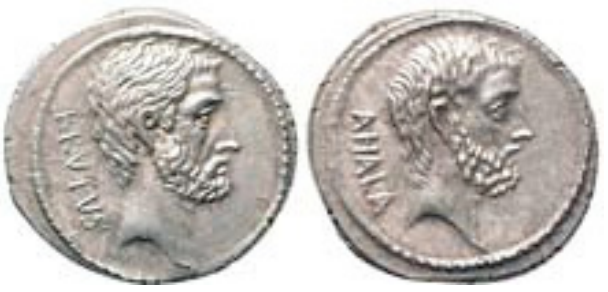

Fig. 12. Brutus, denarius, 54 BC. Obv.: L. Brutus BRUTUS, rev.: Servlius Ahala, AHALA, evoking his two Tyrannicide ancestors $(\mathrm{Cr} 433 / 2)$.

A mint master of $13 \mathrm{BC}$, Sulpicius Platorinus, released a remarkable denarius that has double heads, Augustus and Agrippa (Fig. 10). Similar double headed coins appeared long before then, but Romans in $13 \mathrm{BC}$ were far more likely to recall recent precedents from the last 25 years, rather than during the Republic, and the Republican versions always made a different statement, often that the mint master could be relied upon as a worthy descendent of two noble ancestors (Fig. 11-12). The coins of Lepidus, Antony, and the Young Caesar with double heads suggest the equality of the trio and their global dominance. The last person with whom Augustus had shared a double heads coin was the Divine Julius in 17 BC (Fig. 13) (such double headed coins of Augustus and Julius started in the 40s), so the Augustus/Agrippa coin made a specific statement that Agrippa is worthy so share all with the son of a god. Ca. $10 \mathrm{AD}$, double headed coins of Augustus and Tiberius appear, following this model (Fig. 14). Those who think the coin signals Tiberius' succession as Augustus' heir would have to grant Agrippa the same privilege. Another denarius from $13 \mathrm{BC}$ shows two figures as if tribunes sitting on a bisellum who can be only Augustus and Agrippa, the two holders of tribunicia potestas (Fig. 15). This additional honor asserts the auctoritas of Agrippa.

A second mint-master of 13, Marius Trogus or Tromentina (his cognomen is not reliably known) released multiple versions of Augustus and Agrippa acting as if censors with only slight differentiations from batch to batch, such as with and without the oak wreath around Augustus' head. On these denarii, Augustus and Agrippa appear 


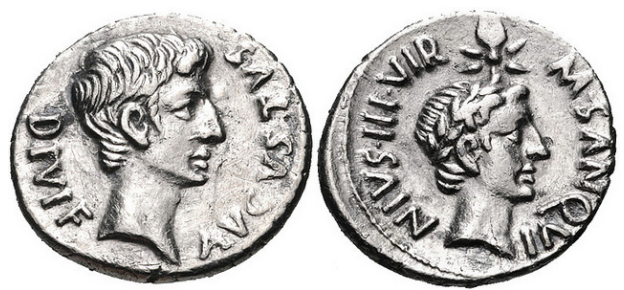

Fig. 13. M. Sanquinius, denarius, 17 BC. Obv.: AVGVSTVS DIVI F, bare head of Augustus, rev.: M SANQUINIUS III VIR laureate head of Divus Julius, comet or sidus Iulialis (RIC I 338, RSC 1).
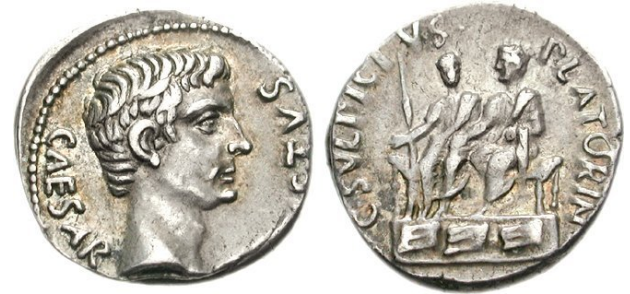

Fig. 15. C. Sulpicius Platorinus, moneyer denarius. Obv.: CAESAR AVGVSTVS, bare head right, rev.: C.SVLPICIVS PLATORIN, Augustus and Agrippa seated left on daïs, ornamented with upright spear and three prows (RIC I 406, RSC 529).

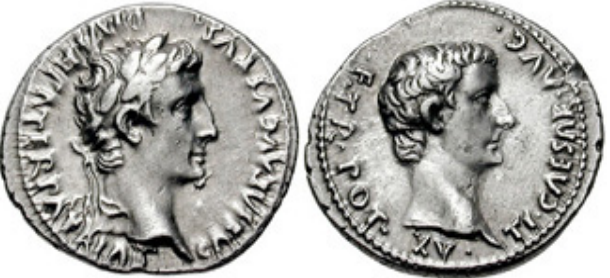

Fig. 14. denarius and aureus Lugdunum mint, 13-15 AD. Obv.: laureate head of Augustus, rev.: bare head of Tiberius.
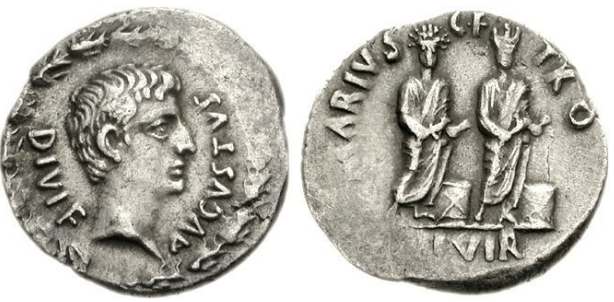

Fig. 16. C Marius C F Tro, 13 BC. Obv.: AVGVSTVS DIVI F, bare head right; rev.: $\mathrm{C} \cdot$ MARIVS C • F TRO, III $\bullet$ VIR in exergue, Augustus laureate, and Agrippa wearing combined mural and rostral crown, both togate, each holding a roll in left hand; at the feet of each, a capsa (RIC I $400=$ RSC $458=B M C R E 107=B M C R R$ Rome $4647=B N 528)$.

to perform the census with scrolls in their hands and capsae at their feet, which they actually did do 15 years prior (Figs. 16-17). The coin is possibly an anniversary commemoration, but certainly it extols the auctoritas of Agrippa. This image is compatible with the coin of Platorinus on which Augustus and Agrippa sit as if tribunes (cf. Fig. 15). Marius also minted a denarius showing an empty quadriga with a palm branch in it on the reverse (Fig. 18). The quadriga is the standard sign of a triumph on coinage, and Agrippa was offered a third triumph in $13 \mathrm{BC}$. He turned it down, for which reason the chariot is empty, so the denarius displays the modesty of Agrippa, for he rejected an honor everyone else would accept. An aureus, also minted by Marius, advertises Augustus' religious credentials on the obverse by presenting both the augural lituus and the pontifical simpulum (Fig. 19). The reverse apparently shows him extending the pomerium or founding a city, however, as Grueber has noted, Augustus never extended the pomerium of Rome. Grueber thought the image likely referred to the founding of Emerita in Hispania in 25 BC. A more recent colony is a better guess. ${ }^{7}$

${ }^{7}$ Grueber, H. A.: Coins of the Roman Republic in the British Museum. Vol. II. London 1910, 94 : "That of the aureus refers to the many colonies founded by Augustus, more specially in connection with the 


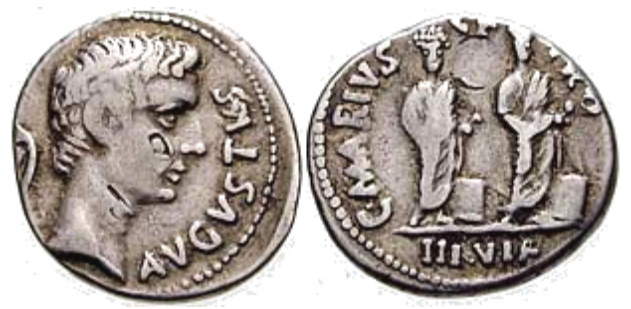

Fig. 17. Marius C F Tro, 13 BC. Obv.: AVGVSTVS DIVI F, bare head right; lituus behind, rev.: C MARIVS C F TRO, III • VIR in exergue, Augustus laureate, and Agrippa wearing combined mural and rostral crown, both togate, each holding a roll, capsa at feet (RIC 397).

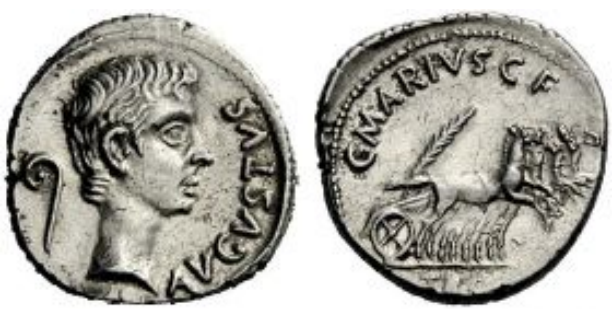

Fig. 18. Roman mint. Obv.: AVGVSTVS, bare head of Augustus, lituus behind, rev.: C MARIVS C F TRO III VIR, quadriga, horses galloping and a long palm branch in chariot (RIC 399). Wrongly dated by Count de Salis to $8-6 \mathrm{BC}$.
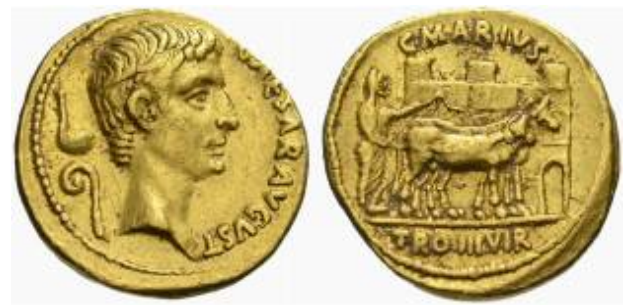

Fig. 19. aureus. Obv.: CAESAR AVGVST, bare headed Augustus with lituus and simpulum,

rev.: C MARIVS TRO III VIR, Augustus, veiled and togate, ploughing with two oxen before city wall

(C 460, Bahrfeldt $185=C B N 514=$ Calicò $138=R I C$ 402).

The next set of denarii, minted by Marius, has been differently interpreted. The early numismatists thought they recognized Augustus on the obverse and his three children on the reverse, namely Gaius, Julia, and Lucius. This identification apparently comes from the mis-dating of the coins to match Augustan legislation providing greater privileges for parents of three children to increase the birth rate. Some feminist and anachronistic fans of Livia claim that Livia is the central figure, but this is absurd. Elaine Fantham, following Mattingly and Grueber writes: "None of the three is named, but despite their miniature size, the young men's profiles resemble Augustus so strongly that they can only be his 'sons', and their mother is there to serve as a blood link between the Princeps and his heirs." I disagree with her logic and her conclusions. Along with Laffranchi and Brian Rose, I think the trio is Augustus, Julia, and Agrippa. (Figs. 20-22). The first figure closely resembles Augustus because he is Augustus. The third figure is Agrippa exactly because the trio returned to Rome in

foundation of the colony of Augusta Emerita in B.C. 23, which became the capital of Lusitania [...]. The type cannot relate to Rome itself as Augustus does not appear to have extended the pomerium of the city."

This coin is cross-referenced as Cr 460. Bahrfeldt $185=$ CBN $514=$ Calicò $138=$ RIC 402.

${ }^{8}$ GRUEBER (n. 7) II 94. 

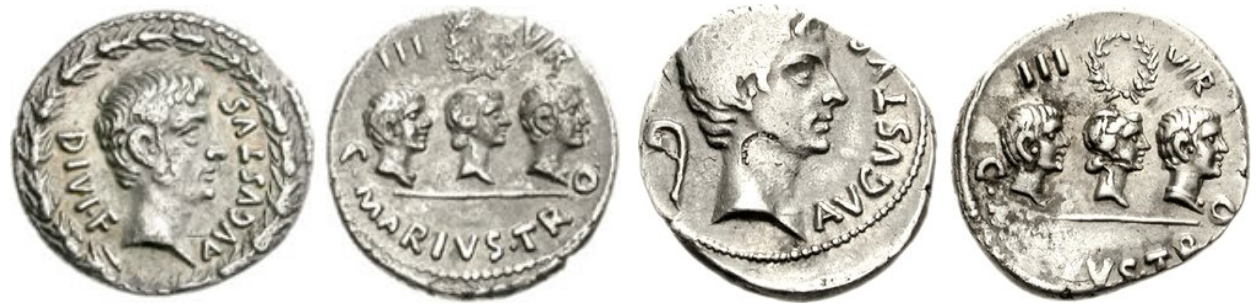

Fig. 20 and Fig. 21. Marius Trogus, denari.

Obv. (left): DIVI F AUGUSTUS, head of Augustus, right, oak wreath;

(right) AVGVSTVS, lituus behind; rev.: C.MARIVSTRO IIIVIR,

Augustus, Julia, Agrippa, wreath above Julia.
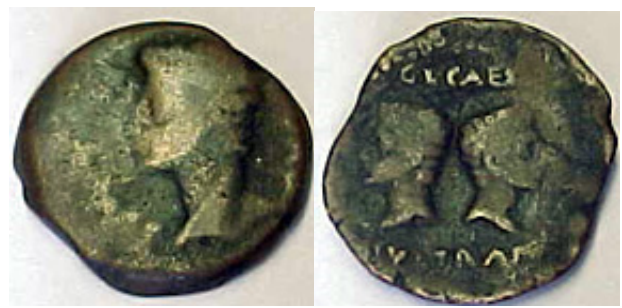

Fig. 22. Augustus aes of Julia Traducta, Hispania. Obv.: PERM CAES AVG, bare head left, rev.: C L CAES IVL TRAD, confronted bares heads of Gaius and Lucius Caesars (Cohen 185, SGI 165) (collection and photo Gaius Stern)

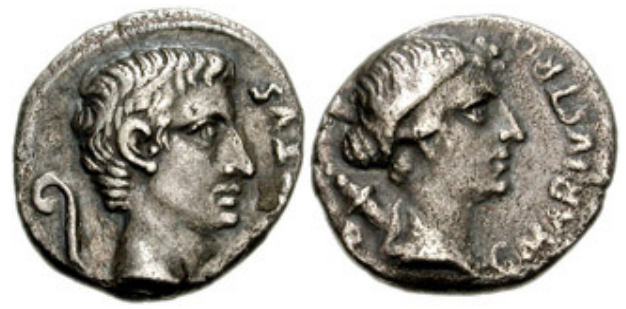

Fig. 23. Marius C F, denarius. Obv.: AVGVSTVS, bare head with lituus, rev.: diademed bust of Julia/Diana with quiver (RIC I 403, RSC 1 [Julia and Augustus]).

summer $13 \mathrm{BC}$. This coin serves as a visual newspaper headline, not as a dynastic statement. One must recall what is so often forgotten, that Augustus was afraid to be too overtly monarchical for fear of a repeat of the Ides of March. Furthermore, Fantham's claim that Julia serves "as a blood link between the Princeps and his heirs", ${ }^{9}$ is utter nonsense, because by law, Augustus was the father of Gaius and Lucius. He had no need to include Julia to establish a relationship to his sons. For exactly the same reason he never put Atia and Julia on his coins to establish his link to the Divine Julius! Fantham's claim would be intelligible only before Augustus adopted Gaius and Lucius in $17 \mathrm{BC}$.

Another coin of Marius shows Augustus and the lituus on the obverse and a figure widely identified as Julia with the attributes of Diana on the reverse (Fig. 23). I personally think it might be Diana herself, but if the coin is Julia as others suppose, this is an indirect reference to Agrippa, whose wife was now honored on coinage. Diana was recognized for contributing to the victories in which Agrippa defeated Sextus Pompey in the Sicilian War, and she appeared on several issues in $15 \mathrm{BC}$. Whether the denarius shows Julia or Diana, both of them can be interpreted as indirect compliments to Agrippa. 2006,67 .

${ }^{9}$ FAnTHAM, E.: Julia Augusti the Emperor's Daughter [Women of the Ancient World]. Routledge 
Marius also minted a denarius of Augustus on the obverse with an oak wreath around the edge while the reverse shows a Pontifex holding a simpulum. (Fig. 24) Most authorities see Augustus on both sides of the coin. Grueber wrote "Augustus, as Pontifex Maximus, veiled, standing L, and holding a simpulum in his r. hand"10 (although some have disputed my suggestion that Augustus appears on both sides of the Augustus-Julia-Agrippa coin on this very ground). This coin actually shows Agrippa as a Pontifex to advertize to the public his sacral dignitas. Augustus became a Pontifex in $47 \mathrm{BC}$ at age of 16, so this late an advertisement is meaningless, whereas for Agrippa, it has newspaper headlines value. We know that Augustus resented the fact that Lepidus held the post of High Priest and looked forward to the day when it would finally fall open. ${ }^{11}$ At the same time, he worried that after he died, someone else might challenge Agrippa, and inevitability made all the worse if the new Pontifex Maximus opposed Agrippa. The best way to prevent this was to hold the post himself and ensure that the post would pass to Agrippa thereafter. Therefore Agrippa had to join the Pontifical College as soon as possible to ease his ascent and to eliminate any possible contender based on sacral law or superior religious authority.

This preventive measure and conscious expanse of Agrippa's religious authority can be seen on two other coins minted by the third mint master of $13 \mathrm{BC}$, Antistius Reginus. On the aureus, two men sacrifice a pig above an altar (Fig. 25) in an image that very closely resembles a denarius from 16 BC (Fig. 26), thought to commemorate the treaty with Gabii some 500 years before.

I think the earlier version from 16 BC shows Augustus and Agrippa sacrificing at the Ludi Saeculares, as we read in Horace. The version from 13 BC apparently shows them sacrificing a pig - the animal of peace sacrifices - perhaps at a closure of the Gates of Janus or at the Ara Pacis ceremony. The fact that from both issues the coin legend mentions foedus puzzles me. Other scholars say it refers to the treaty with Gabii 500 years prior.

The denarius minted by Antistius Vetus in $16 \mathrm{BC}$ showed four religious symbols for the four top religious colleges and the reverse legend COS IMP CAESAR AUGU XI (Fig. 27). ${ }^{12}$ The goddess on the obverse is often identified as Venus or Honos. This denarius is thought to signal when Augustus entered the college of the Septemviri Epulones and raised it in standing to the big four. The version from 13 BC (Fig. 28) makes the same statement about Agrippa's entry into the four top religious colleges, a premise that is supported by literary, epigraphic, and numismatic evidence.

${ }^{10}$ GRUEBER (n. 7) II 94.

${ }^{11}$ Tiberius received the same honor of multiple priesthoods in AD 5 shortly after Augustus adopted him, and likewise Germanicus and Drusus received multiple priesthoods from Tiberius. M. H. LEWIS (The Official Priests of Rome under the Iulio-Claudians: A Study of the Nobility from 44 B.C. to 68 A.D. American Academy in Rome 1955, 43, 52, 58-59) dated Tiberius' entry into the college of the Quindecimviri to ca. AD 4, CIL 5.6416 = ILS 107; his entry into the college of the Augurs to AD 4/5 based on a coin; and Tiberius' entry into the college of the Septemviri between AD 4 and 15. An early date is to be preferred. Much later, upon becoming emperor, both Caligula and Claudius immediately joined the other three major colleges (they each already held one of the four major priesthoods). Likewise, Claudius enrolled Nero in all four major priesthoods to mark him as the next emperor in AD 52.

${ }^{12}$ Antistius Vetus, son of Caesar's legate in Gallia and the friend of Cicero (Ad Att. 10. 12). 

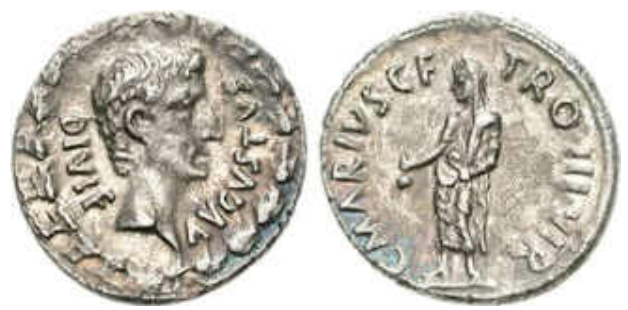

Fig. 24. Marius C F Tro(mentina tribu), denarius. Obv.: AVGVSTVS DIVI F, bare head right, all within oak wreath, rev.: C MARIVS C F TRO III

VIR, Pontifex, veiled and togate, holding simpulum in right hand (RIC I 401, RSC 455a, cf. $B M C R E$ p. 22, note; $B N 527)$.
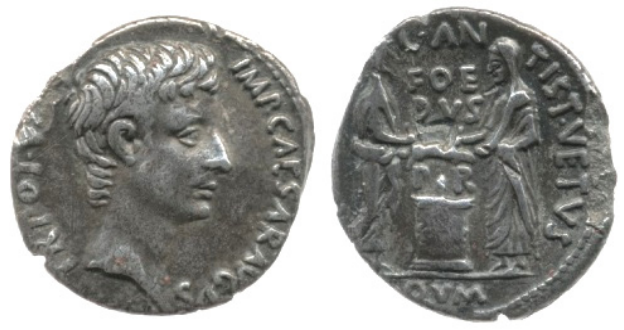

Fig. 26. Antistius Vetus, denarius. Obv.: IMP

CAESAR AVGVS TR POT VIII, bare head of Augustus, rev.: C ANTIST VETVS FOR DVS P R QVM GABINIS, two veiled priests holding pig over altar right.

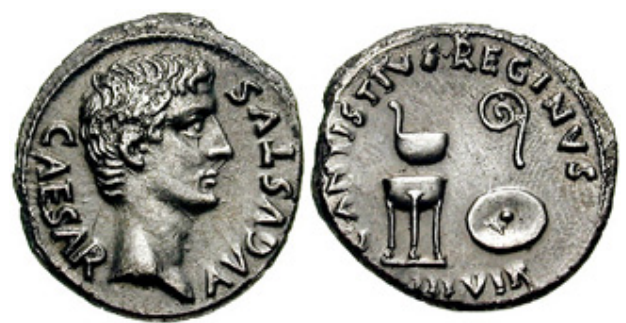

Fig. 28. C. Antistius Reginus, denarius. Obv.: CAESAR AVGVSTVS, bare head right, rev.: $\mathrm{C} \cdot \mathrm{ANTISTIVS} \cdot \mathrm{REGINVS} \mathrm{III} \bullet$ VIR,

sacrificial implements: simpulum and lituus above, tripod and patera Rome 4661-4662; BN 542-547).

$$
\text { (RIC I 410, RSC 347, BMCRE 119-120= BMCRR }
$$

Fig. 25. Antistius Reginus, aureus.

Obv.: CAESAR AVGVTVS, oak-wreathed head, rev.: C·ANTIST·REGIN GABINVS FOEDVS, two veiled priests facing each other, sacrificing a pig over a lit and garlanded altar, below: P R QVM (Bahrfeldt 184.1 = Calicó $123=\mathrm{B}$. Antestia $17=B M C 118$; C 346; CBN p. $113^{*}=$ RIC 411).
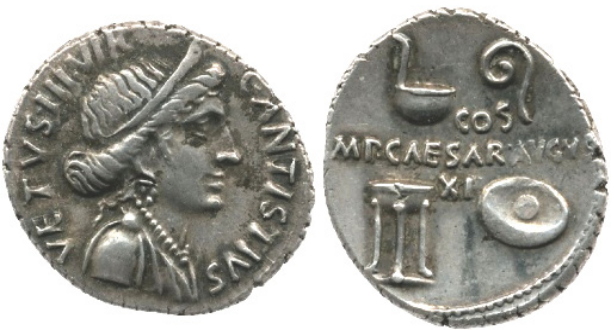

Fig. 27. Antistius Vetus, denarius 16 BC. Obv.: C • ANTISTIVS • VETVS • III • VIR, diademed and draped bust of Venus right, rev.: IMP CAESAR AVGV S, COS/XI in two lines above and below, simpulum, lituus, patera, tripod (RIC I $368=R S C$ $348 \mathrm{a}=B M C R E 98$ note $\approx B N 368$ var). 
When Augustus elevated Tiberius, he enrolled in the top four religious colleges. ${ }^{13}$ When Tiberius planned to purge Seianus, he allowed Seianus to think he was being elevated to multiple priesthoods as the step before his accession, and then struck him down once Seianus was off guard. When Claudius promoted Nero above his own son Britannicus to be his heir, he enrolled him in the top four religious colleges and released an issue of aurei and denarii to advertise that fact to the world (Figs. 2930). The similarity to the Augustan reverses was highly deliberate, for Claudius often meticulously copied earlier precedents.

Finally we turn to three denarii released in early 12 BC, probably before Agrippa's death in March. On the first, Augustus and Agrippa again appear as two heads to suggest equality, but with markedly different headgear. Augustus wears his oak wreath, while Agrippa wears his special mural and rostral crown, a special marked honor that he alone enjoyed at that time (Fig. 31). ${ }^{14}$ The simple message equates the powers of the two men, who now possessed equal legal authority. To me, this coin acknowledges publicly that Agrippa is the socius imperi, or if you prefer, socius regni. The second denarius has been interpreted as a statue of the late Agrippa issued in a large release for his funeral to help comprise the donative he bequeathed to every Roman citizen. In my opinion, the coin clearly shows the spolia opima, won by the ancestor of the mint master Cossus Cornelius Lentulus in a show of personal advertisement entirely unrelated to Agrippa (Fig. 32).

Another denarius minted by L. Cornelius Lentulus in $12 \mathrm{BC}$ is sometimes associated with Agrippa, but in my opinion incorrectly, even though this would support my thesis. On it one figure holds a star above the head of the other. The second smaller figure holds a victory (Fig. 33). Some scholars ${ }^{15}$ have suggested this denarius shows

${ }^{13}$ The same honor was given to Tiberius in AD 5 after his adoption by Augustus, and by Tiberius to Germanicus and Drusus. Upon becoming emperor, both Caligula and Claudius immediately joined the major colleges. Nero was enrolled in all four major priesthoods to mark him as the next emperor in AD 52 . LEWIS (n. 11) 43, 52, 58-59 dated Tiberius' acquisition of the Augurate to AD 4/5 based on a coin and his entry into the college of the Quindecimviri to ca. AD 4, CIL 5. $6416=I L S 107$. Lewis would date Tiberius' entry among the Septemviri between AD 4 and 15. An early date is to be preferred for political reasons, probably 7 Jan. AD 5. To raise Seianus' hopes an expanse of powers including multiple priesthoods were hinted, Suet. Tib. 65; Dio 58. 7. 4-5. On Germanicus, Drusus the Younger, Caligula, Claudius, and Nero, see Chapter 3.1.

${ }^{14}$ GRUEBER (n. 7) II 96 correctly noted that the Senate confirmed Agrippa's privilege to wear this naval crown on all such occasions when those who had triumphed wore their laurel crowns (Dio 49. 14; Vell. 2. 81). Pliny Hist. Nat. 16.3, however, relates that Pompey had granted a similar crown to M. Varro for his victories over the pirates.

${ }^{15}$ H. MATTINGLy (Roman Imperial Coinage. London 1923, I 415) suggested this denarius shows Augustus crowning the late Agrippa (who was especially tall) with a star as part of the funerary issue along with the equestrian statue mentioned above, followed by J. D. NEWBY (A Numismatic Commentary on the "Res Gestae" of Augustus. Iowa City 1938, 52-53), S. MCBRIDE ("Augustus standing facing, resting hand on shield, crowning Agrippa, who holds Victory and spear" at http://wildwinds.com/coins/ric/ augustus/RIC_0415.txt [August 2005], J. GERANIO (at https://www.forumancientcoins.com/numiswiki/ view.asp?key=Agrippa\%20Denarii), however the coin remains much disputed. For a discussion of the identities of the figures on the coin, see FULLERTON, M.: The Domus Augusti in Imperial Iconography of 13-12 BC. AJA 89 (1985) 473-483; STERn, G.: Women, Children, and Senators on the Ara Pacis Augustae. Diss. Berkeley 2006, 130-132; Koortbojian, M.: The Divinization of Caesar and Augustus. Cambridge University Press 2013, 144-146. 

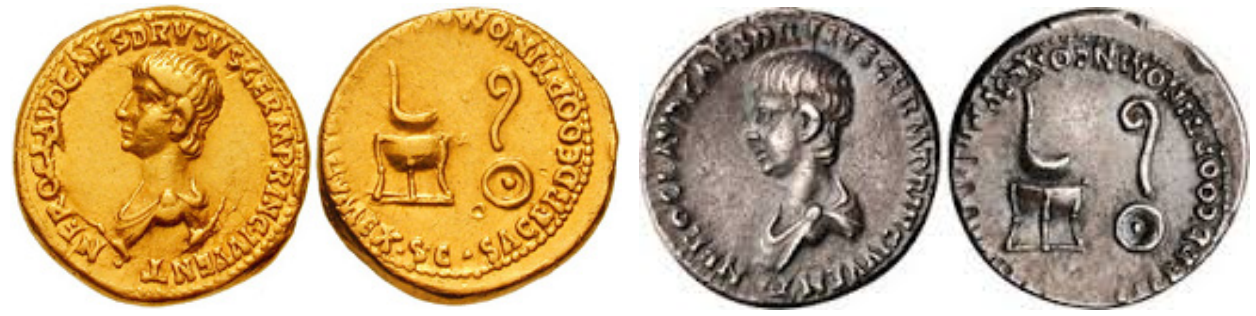

Figs. 29 and 30. Claudius, AD 52/53, denarius and aureus.

Obv.: NERO CLAVD CAES DRVSVS GERM PRINCI IVVENT - Bare-headed teenage Nero, rev.: SACERD COOPT IN OMN CONL SVPRA NVM SC, simpulum, lituus, patera, tripod.
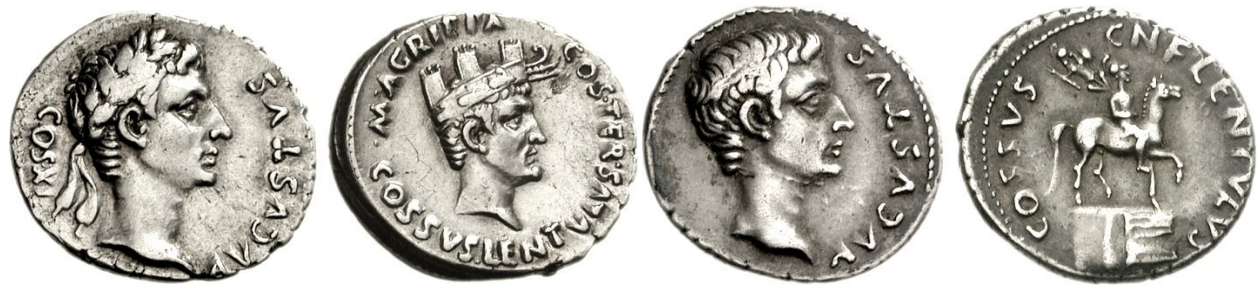

Fig. 31. Cossus Cornelius Lentulus, denarius 12 BC. Fig. 32. Cossus Cornelius Lentulus, denarius 12 BC. Obv.: AVGVSTVS COS $\bullet$ XI, head of Augustus wearing oak wreath, rev.: $\mathrm{M} \cdot \mathrm{AGRIPPA} \cdot \mathrm{COS} \cdot$ TER $\bullet$ COSSVS $\bullet$ LENTVLVS, head of Agrippa wearing mural and rostral crown $(R I C$ I $414=R S C 1$ [Agrippa and Augustus] $=B M C R E 121=B M C R R$ Rome $4671=$ BN 548-550).

Obv.: AVGVSTVS, bare headed, rev.: COSSVS

$\mathrm{CN} \cdot \mathrm{F} \cdot \mathrm{LENTVLVS}$, equestrian statue right of Cornelius Cossus, helmeted, bearing spolia opima over left shoulder, on pedestal, ornamented with two prows $(R I C$ I $412=R S C 418=B M C R E 122-$ $123=B M C R R$ Rome 4672-4673 = BN 551-554).
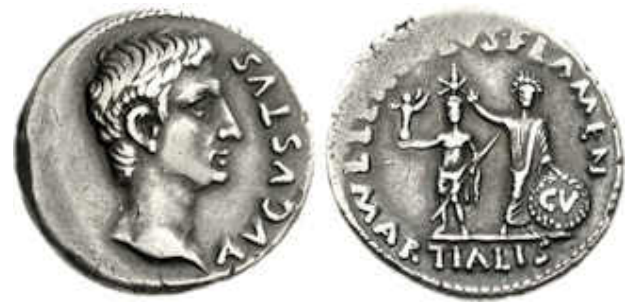

Fig. 33. Lentulus, denarius $12 \mathrm{BC}$.

Obv.: AVGVSTVS, bare headed,

rev.: L • LENTVLVS • FLAMEN MARTIALIS, one figures places a star over another who holds Victory and a spear; shield inscribed CV $(R I C$ I $415=R S C 419=B M C R E$ 124-125 = BMCRR Rome 4674-4675, BN 555-559).

GRUEBER (n. 7) II 102 preferred Augustus crowning the Divine Julius: “Augustus ... places a wreath on the head of the statue of Julius Caesar, facing, holding a Victory in r. hand, and a spear in 1.; a star above the head of Julius Caesar." 


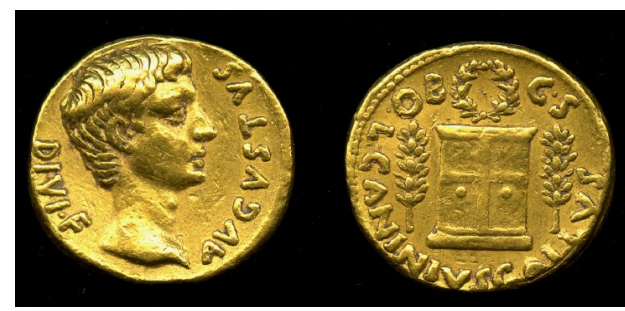

Fig. 34. Caninius Gallus aureus $12 \mathrm{BC}$. Obv.: AVGVSTVS DIVI F, head of Augustus right, wearing oak wreath, rev.: L CANINIVS GALLVS, OB C $\bullet \mathrm{S}$, laurel wreath above double closed door flanked by laurel branches.

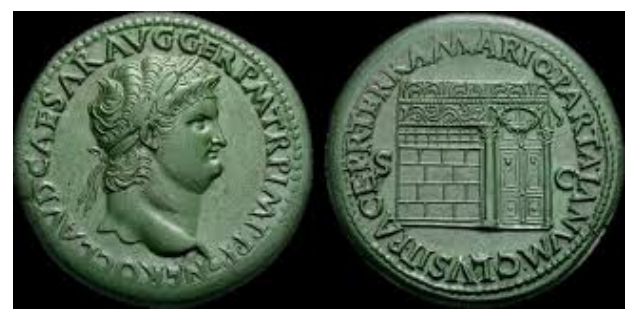

Fig. 35. Neronian aes showing the closed Gates of Janus.

Augustus crowning the late Agrippa (who was especially tall) with a star as part of the funerary issue along with the equestrian statue mentioned above. This interpretation would certainly support my claim that Agrippa's star was on the rise in 13 BC to the standing of junior emperor, but the coin appears to infer a divine status on the second figure, which might be a statue rather than a person. I suspect the denarius has nothing to do with Agrippa, but marks the 40th anniversary of Philippi. The best guess is that the Divine Julius, holding Augustus' clipeus virtutis places a sidus Iulialis over the head of a statue resembling the Prima Porta Augustus (Figs. 34-35). ${ }^{16}$

Even without this denarius, the case for Agrippa's elevation to junior emperor is exceedingly well documented by his ever expanding legal powers and honors and his increased dignitas by means of triumphs and triple consulships, and as I suggest priesthoods. The Ara Pacis also provides much documentation of Agrippa's elevation in a number of ways. First of all, much of the peace celebrated by the Ara Pacis resulted from Agrippa's conquests and recent activities in the East. The Parthian child hanging onto his toga reminds the audience that Agrippa played a major role in the East (Fig. 36), although in fact the focus of his activities was the Bosporus region in 14/13 BC rather than the Parthian border. In a very real sense, the success of Rome hinged upon this man's superior abilities and reputation, for which he was much more highly respected abroad than by certain magnates in Rome. Some elitist aristocrats may have scorned his modest origins, but he completely eclipsed their abilities and powers. If he lacked superior breeding "and plodded like a man for working days ... he rose ... with so full a glory that he dazzled all the eyes" of Rome and struck his rivals "blind to look on" him. And he could make them eat dirt if they did not like it, and had done so many times in the past, at Mutina, Mylae, Naulochus, and Actium, to name a few.

${ }^{16}$ See also an aureus minted by Caninius Gallus whose obverse bears the legend AVGVSTVS DIVI F, but whose reverse depicts closed doors with an oak crown above and laurel trees beside them. Scholars have traditionally identified this as Augustus' front door on the Palatine, which the Senate distinguished with these adornments in $27 \mathrm{BC}$ for saving citizens' lives by ending the civil wars. However, another possible interpretation is that the doors are the closed Gates of Janus. While this coin does not resemble Nero's issue nearly a century later, that is not a disqualifier: Nero did not copy Augustan coin imagery as meticulously as Claudius. 


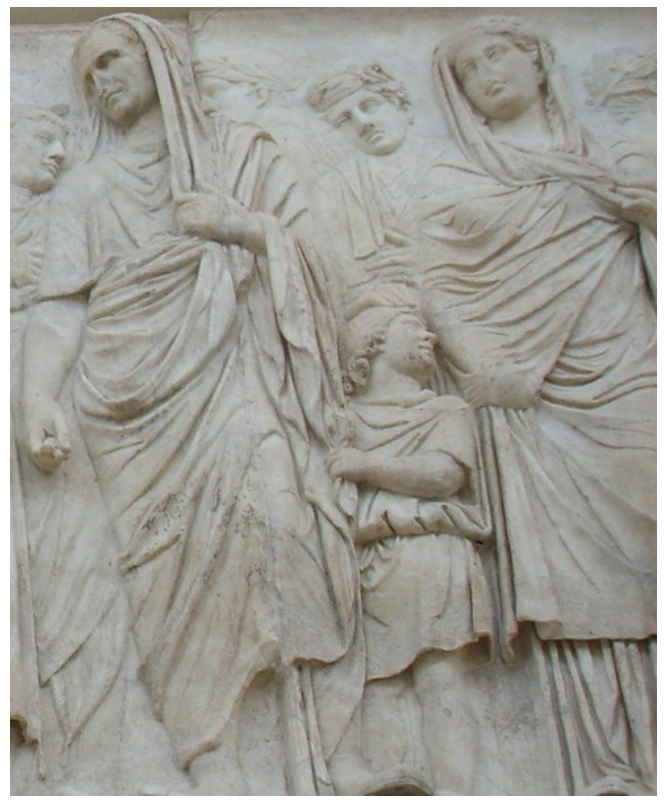

Fig. 36. Ara Pacis. Parthian child hanging onto Agrippa's toga. (Photo Gaius Stern)

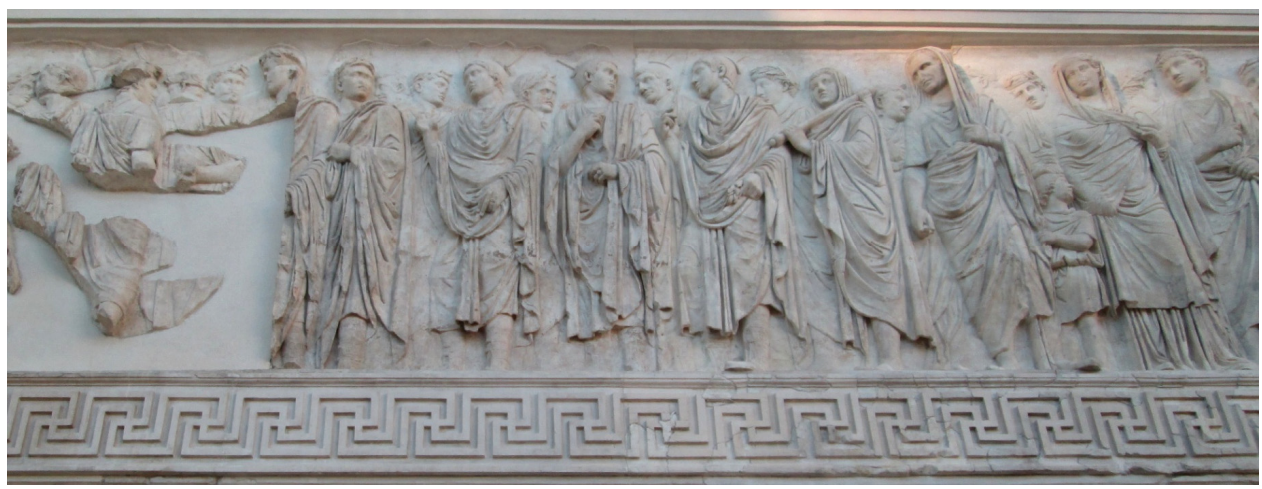

Fig. 37. Ara Pacis, South Wall. Pontifices, including Agrippa with covered head (Photo Gaius Stern)

On the Ara Pacis we first have ten lictors, followed by the Pontifical College, including Augustus. Other Pontifices follow, including Agrippa in almost a central position on the South Wall to attract attention (Fig. 37). His covered head shows his status as an officiating priest - this time within the Pontifical College. The presence of Agrippa and his wife Julia displays both domestic tranquility, as do the other marriages within the imperial family, and also the stability that Agrippa, as Augustus' son-in-law, will maintain should anything happen to Augustus. In more ways than one he is a transition figure, for not only will he preserve Rome if Augustus dies suddenly, here he appears in the Pontifical College and simultaneously begins the family 


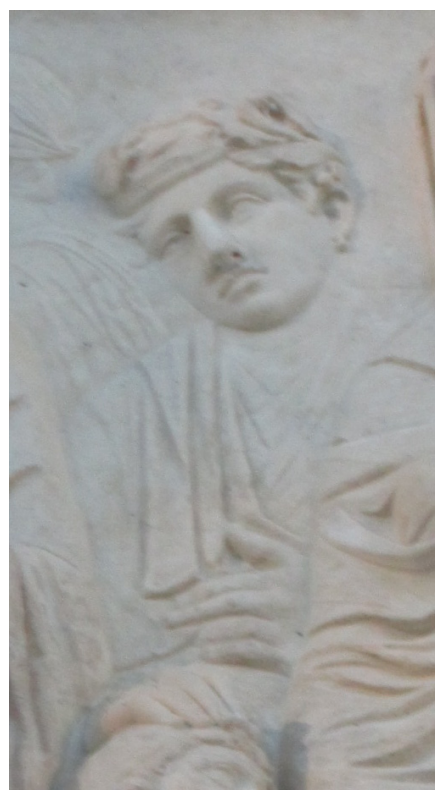

Fig. 38. Ara Pacis. Vipsania Tertia (Photo Gaius Stern)

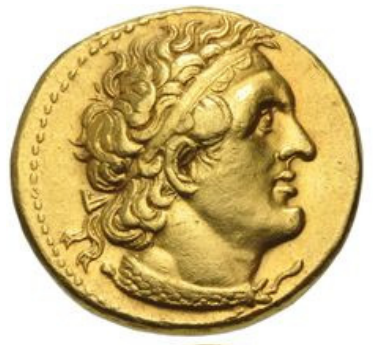

Fig. 39. Stater of Ptolemy I

(https://www.mouginsmusee.com/en/collections/greek-and-roman-coins)
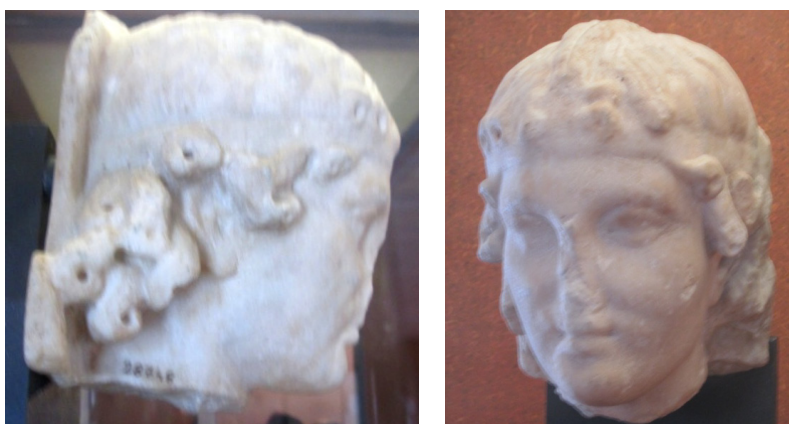

Fig. 40. Roman girl of the 1st century AD wearing a brill (not a diadem) (Verona Archeological Museum; photo Gaius Stern) 
procession of his own dependents: his wife Julia, the foreign prince they are fostering, his daughter(s), and his sons-in-law.

The issues of family and domestic tranquility are further played up by the girl in the background behind Agrippa, whom Brian Rose has argued is Dynamis of Bosporus, reaching out from the background to touch the Parthian guest-hostage on the head. ${ }^{17}$ The young lad has come to be fostered in the home of Agrippa and Julia and to learn Roman ways. She is young Vipsania Tertia, the daughter of Agrippa by his second wife, Claudia Marcella, and she adds a new dimension to Agrippa's role as a perfect Roman father of many children, a role model for others. No modern scholar has commented how odd it is that Augustus and Agrippa appear without their children, for Agrippa had five daughters, with a posthumous son on the way, and especially considering Augustus' natalist legislation. After all, children escort Drusus and other members of the Imperial Family. In truth, most scholars in the $1920 \mathrm{~s}^{18}$ assumed that Livia, Gaius, and Lucius as a family group occupied the undiscovered front of the South Frieze of the Ara Pacis, until the 1936 excavation under Moretti found only lictors. ${ }^{19}$ The desire for Agrippa to appear with his son(s) contributed to the longevity of Petersen's absurd claim that one of Agrippa's sons dresses as a foreigner and tugs on his toga.

Vipsania is clearly a Roman girl wearing a brill, not a diadem (Fig. 38). She wears her brill above her ears nearly horizontally, whereas a real diadem, like that of Ptolemy I on this stater, is worn at a 45 degree angle (Fig. 39). Vipsania Tertia's presence, shortly before she married Q. Haterius, adds the role of father to Agrippa on the monument, for Agrippa's other (legal) children are not seen on the monument (if they were ever there). She might be 14 . I was unable to prove my case against Rose's diadem until 2014, when I found a bust of a Roman girl from the 1st century AD wearing a brill in the Verona Archeological Museum that makes my case (Fig. 40). She touches the boy's head as a gesture of affection, perhaps indicating she is on the path to marriage and motherhood in the near future.

Thus the Ara Pacis extols Agrippa as a man of vision, a man excelling at the arts of war and peace, a man for the future, a man trusted and protected by the gods, and a proper father of a large family. But we know something the designers of the Ara Pacis could not, namely that Agrippa's death ruined the peaceful Golden Age Augustus hoped to inaugurate and dashed all his plans to ashes. Nevertheless, the composition of the Ara Pacis presents an optimistic picture to prognosticate a happy and prosperous future that never materialized. Even though Agrippa died on March 12 $\mathrm{BC}$, six months into the construction of the Ara Pacis, the artists and the regime

${ }^{17}$ Rose, B.: Princes and Barbarians on the Ara Pacis. AJA 94 (1990) 453-467.

${ }^{18}$ DomaszewsKI, A. vON: Die Familie des Augustus auf der Ara Pacis. JÖAI 6 (1903) 57-66. See p. 66 that Livia and Julia must be ahead of Augustus on a yet-undiscovered (in 1903) panel. This opinion is referred to in MONACO, G.: L'iconografia imperiale nell' Ara Pacis Augustae. Bull. del Comm. di Roma 62 (1942) 17-42, see 24, but Monaco later reveals that it was out of date.

${ }^{19}$ MoretTI, G.: La ripresa dello scavo dell'Ara Pacis Augustae. Notizie degli scavi 6 (1937) 37-44, Ara Pacis Augustae (Roma 1938), Ara Pacis Augustae (Rome 1948). The 2nd item is the very small booklet published in several languages with details about the excavation and people on the monument. The 3rd item (Same name!) is the major tome 30 inches tall that only libraries buy, published posthumously. 
retained the original design that included him, thinking the Golden Age he had thus far nobly advanced would still come about, although with each successive season the Age of Peace drew further and further away. All the same, the regime (Augustus) could hardly admit so soon after Agrippa's death that the agenda it (Augustus) had so clearly defined to the public was a dead letter, and it may well have had difficulty recognizing or admitting it to itself.

\author{
Gaius Stern \\ University of California, Berkeley \\ History of Art (Rome, Greece) \\ 431 Doe Library \\ Berkeley, CA 94720
}

